\title{
UM ESQUEMA GERAL PARA A DISCUSSÃO DO MOVIMENTO DE MATERIAIS PARA AS CÉLULAS VIVAS E TECIDOS
}

\author{
T. C. BROYER * \\ E. MALAVOLTA **
}

fNDICE

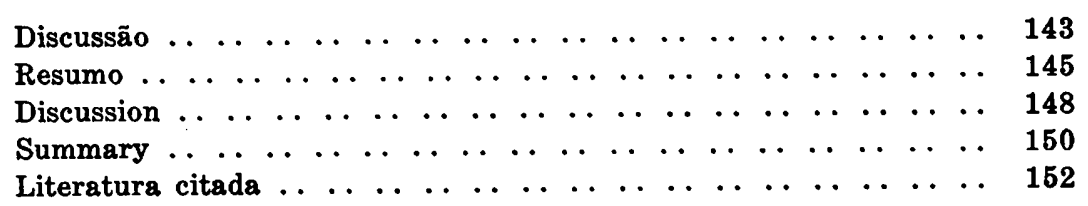

* Department of Plant Nutrition, University of California, Berkeley, Calif., U. S. A.

** Seç̧ão Técnica de Química Agrícola, E. S. A. "Luiz de Queiroz", Universidade de São Paulo. 
Foram publicados numerosos trabalhos de pesquisa estabelecendo vários passos e estudando a influência de vários fatores no movimento de materiais para células e tecidos $(12,14$, $16,17,19)$. De tempos em tempos aparecem revisōes da literatura coordenando os fatos experimentais sôbre a migração de solutos ou da água $(2,3,4,5,8,9,10,15,25)$. Frequentemente tais revisões são de natureza puramente descritiva tratando prolixamente das possiveis fases do processo e das relaçōes energéticas do mesmo. Diversos diagramas especializados foram publicados estudando ora o movimento de solutos, ora a migração da água ou então fases particulares de cada um. Alguns desses esquemas foram feitos considerando-se sistemas animais $(6,7,13,21)$ e outros, sistemas vegetais $(3,4,5,8,16$, $17,19,22)$. Ainda que em cada caso particular possam ocorrer reações especiais, estando implicados componentes específicos, - estado atual dos nossos conhecimentos nos leva a visualizar um aspecto comum nos mecanismos responsáveis pelo movimento de materiais para sistemas vivos. Tais mecanismos são (5): difusão simples ou de Donnan, interação entre o citoplasma e a substância cuja migração nos interessa, adsorção por troca, e absorção metabólica ou "ativa" (absorção contra gradiente de concentração). No presente trabalho sugerimos um esquema geral que abrange os conceitos atuais sôbre esse assunto. Esperamos que o nosso diagrama dê tanto ao investigador como ao professor uma idéia de conjunto a respeito da dinâmica do movimento de materiais.

O diagrama (figura 1) é baseado em noções resumidas por vários autores $(4,5,9,11,14,15,17,18,20,22,23)$; ele inclúe sugestões sôbre o movimento independente tanto de solutos como de água através duma membrana diferencialmente permeável, viva. Ainda que o diagrama considere especificamente uma única célula vacuolada num meio dado, ele pode ser aplicado para a discussão dos movimentos através dum tecido colocado entre um meio externo e uma fase interno e uma fase interna aquosa, como por ex., os vasos do xilema. Quando o meio externo é o solo, então estamos em presença tanto de soluções como de coloides. O mesmo se aplica internamente, si houver coloides nessa fase. Entre células, o movimento pode se dar ao longo de conexões protoplasmáticas, de acordo com mecanismos incluidos aqui, ou encarando-se uma célula de referência como sendo uma membrana viva separando duas fases animadas e que podem ser tidas, uma interna e outra externa. Aqui, embora em estado dinâmico, supõe-se que num dado instante as duas fases atingam um equilíbrio. 
Os niveis energéticos (22) e a mecânica se aplicam tanto para o movimento de água como para de soluto (11). A equação osmótica $(3,10)$ abrangendo diversos fatores, nāo é considerada nas suas partes, mas apenas do ponto de vista da diferença de energia que resulta entre fases - o deficit na pressão de difusão da água (ver 3 ). Troca por contacto e migração superficial de solutos (15) também se enquadram no esquema. $O$ componente $X$ pode tanto ser fornecido inicialmente pelo meio externo ou ser produzido metabòlicamente no citoplasma. No último caso a água e especialmente ácidos orgânicos (4) podem estar implicados; os ácidos orgânicos são de interesse particular no que se refere à acumulação diferencial de iônios de carga oposta.

O diagrama se destina ao investigador já mais ou menos familiarizado com a literatura a respeito dos processos gerais de penetração de solutos. Por outro lado julgamos que tenha alguma utilidade didática para os professores que devem dar aulas sôbre esse assunto.

\section{DISCUSSĀO}

Tratando-se de organismos vivos em determinadas condições, as substâncias tendem a se mover independentemente, a água ou cada soluto migrando na direção em que diminue sua intensidade energética (2). Sob quaisquer condições, a tendência para movimento num instante dado, será expressa em termos da energia livre especíicada (NIF) que causa o movimento dum componente através do citoplasma interposto entre duas fases aquosas inanimadas, ou seja (2)

$$
\mathrm{NIF}=\Sigma \mathrm{IF}-\Sigma \mathrm{E} F .
$$

A intensidade do movimento dum soluto é proporcional ao gradiente do influxo de energia livre específica (NIFG), em que o coeficiente de proporcionalidade $(\mathrm{K})$ é determinado pelas propriedades físico-químicas do citoplasma. Em outras palavras, a intensidade do influxo resultante é igual ao produto de um coeficiente de fluxo ou "permeabilidade" do citoplasma com o gradiente da intensidade de energia, i. é.,

$$
\mathrm{RNI}=\mathrm{K} \times \mathrm{NIFG} \text {. }
$$

Aqui, esse gradiente é uma medida da variação no espaço do influxo, de energia livre específica com dimensōes de 
mL-2t-2. A permeabilidade, uma propriedade do citoplasma, por definição é igual à massa dum componente que se move, na unidade de tempo, através duma área unitária de membrana sob um gradiente - também unitário - de intensidade de energia.

Podemos resumir da maneira seguinte a análise dimensional de "permeabilidade" do citoplasma e a intensidade do influxo dum soluto ou da água : o coeficiente de fluxo ou "permeabilidade" se define pela relação dimensional

$$
\mathrm{K}=\frac{\mathrm{m}}{\mathrm{t}} \times \frac{1}{\mathrm{~L}^{2}} \times \frac{1}{\frac{\mathrm{m}}{\mathrm{L} \mathrm{t}^{2}} \frac{1}{\mathrm{I}_{i}}}=\mathrm{t} \text {; }
$$

a intensidade de fluxo resultante se define pela equação dimensional

$\mathrm{RNI}=\mathrm{t} \times \frac{\mathrm{m}}{\mathrm{Lt}^{2}} \times \frac{1}{\mathrm{~L}}=\frac{\mathrm{m}}{\mathrm{L}^{2} \mathrm{t}}=\mathrm{mL}-2 \mathrm{t}-1 ;$

A permeabilidade pode depender parcialmente dos coeficientes de partição (1) da substância $X$ em solventes citoplasmáticos efetivos, ou de outros característicos fisiológicos. Como a espessura da membrana citoplasmática não é geralmente conhecida, supondo-se constante durante o tempo $t$, o coeficiente defluxo foi expresso dum modo mais prático omitindo-se o fator espessura da membrana nas expressões $c$ e $d$. As dimensões da "permeabilidade" são então tL-1 (cf. (1); as dimensões da intensidade de influxo são as mesmas anteriores, isto é, mL-1t-1.

A energia livre específica do influxo, representada dimensionalmente por $\frac{m}{I t^{2}}$ nas equações $c$ e $d$ pode ser computada a partir do estado de equilibrio, pela diferença entre $\Sigma$ IF e $\Sigma$ EF, ou seja, é igual à diferença de nível representada no diagrama por XFe e XFi $(2,3,4)$.

A "espessura" fisiológica do ectoplasma e do endoplasma pode variar inversamente, em função de fatores ambientais (aeração, pH, etc.) graças a modificações introduzidas em processos físico-químicos, dentro de limites determinados pelas características genéticas do organismo. O mesoplasma indica aqui apenas uma fase de transição do citoplasma de espessura 
indefinida e possivelmente sem consequência. A permeabilidade do citoplasma é determinada pela intensidade de certos processos, limitados pelas potencialidades hereditárias do indivíduo.

\section{RESUMO}

Nêste trabalho é apresentado um esquema geral sôbre o movimento de materiais na direção de células vivas e de tecidos. Destina-se ao uso de investigadores e professores que tenham já algum conhecimento do assunto e estejam familiarizados com a literatura a respeito.

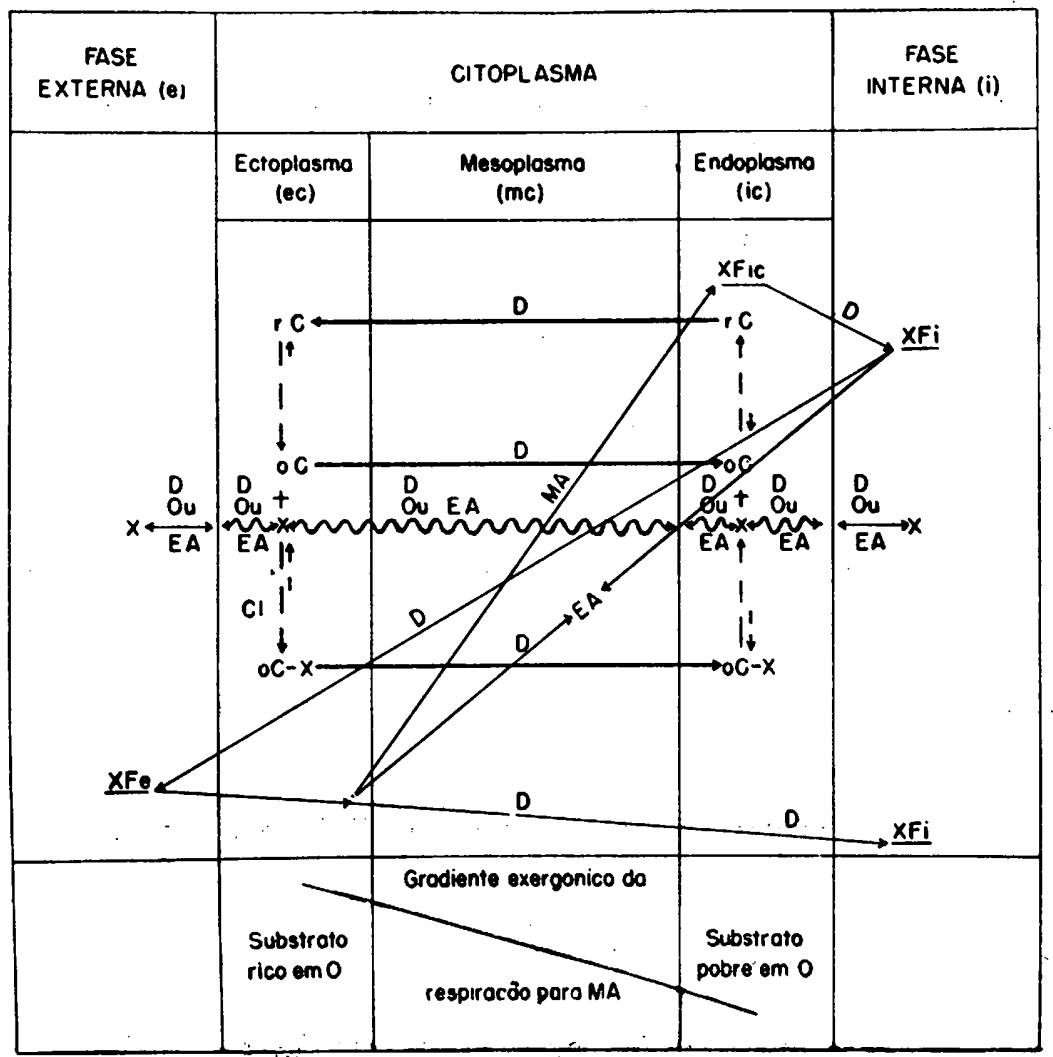

Fig. 1 -Diagrama geral sôbre o movimento de materiais através do protoplasma entre um sistema de duas fases. (Para explicação, ver pág. seguinte). 


\section{Notas à Fig. 1}

$\mathrm{X}=$ qualquer material resultante de fontes externas ou $\mathrm{a}$ través do metabolismo e capaz de migração em condições favoráveis;

e, i, ec, ic, mc = subscritos indicando posição;

oC $=$ constituintes citoplasmáticos oxidados implicados na translocação unidirecional (aqui para dentro) do material $\mathrm{X}$;

$\mathbf{r C}=$ constituinte citoplasmático reduzido;

$\mathrm{XF}=$ energia específica livre (2) de um constituinte na fase externa ou interna do citoplasma;

$\mathrm{D}=$ difusão (4);

$\mathrm{EA}=$ troca por contacto $(4)$

MA = acumulação metabólica;

$\mathrm{CI}=$ interação citoplasmática diferencialmente característica (4) entre OC e X, determinada pela constituição genética;

$\longrightarrow=$ migração, onde a permeabilidade do material é alta;

mamm $=$ migração, onde a permeabilidade do material é baixa;

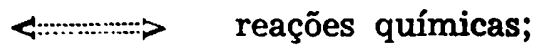

$\longrightarrow=$ modificações energéticas em $X$; a difusão se dá a favor do gradiente de concentração; EA pode se dar a favor ou contra o gradiente de concentração. 


\section{A GENERALIZED COMPREHENSIVE SCHEME FOR DISCUSSION OF THE}

\section{MOVEMENT OF MATERIAL INTO LIVING CELLS AND TISSUES}

Numerous research articles have been published setting forth various steps in, and the influences of modifying factors on, the movement of materials into cells and tissues $(12,14,16$, $17,19)$. From time to time reviews have coordinated the experimental facts of either solute or water migration $(2,3,4,5,8$, $9,10,15,25)$. Frequently these latter were of purely descriptive nature dealing at lenght with the possible steps involved and the energetics thereof. Several specialized illustrative diagrams have been published, usually dealing with either solute or water flux alone or restricted steps of each. Some were designed to apply to animal systems $(6,7,13,21)$ and others to plant systems $(3,4,5,8,16,17,19,22)$. Although specialized reactions and specific constituent components may be involved in a particular case, our current knowledge leads one to visualize a fairly common pattern of mechanisms involved in the movement of materials into living systems. These include simple and Donnan diffusion, cytoplasmic interaction with the constituent component whose migration is of interest, exchange adsorption, and metabolic or "active" absorption. It is the purpose here, to suggest a generalized, comprehensive diagrammatic scheme correlating the current concepts of this subject. It is hoped that such a diagram will give both investigator and teacher an over-all picture of the dynamics of the movement of materials.

The present diagram (figure 2) is based on concepts outlined by various authors, elsewhere $(4,5,9,11,14,15,17,18,20$, $22,23)$. It includes suggestions on the independent movement of both solutes and water across a living differentially permeable membrane interposed between an external and an internal phase. While the diagram is specifically designed to apply to a single vacuolate cell in a given medium, it may be used equally well for discussion of movements across a tissue between an external bathing medium and an internal aqueous phase, e.g., the xylem vessel medium. Where the external medium is a soil, both solutions and colloidal conditions are involved there. The same may apply internally, if colloids are pre- 
sent within this phase. Between cells, the movement may be along interconnecting protoplasmic strands by mechanisms here included or by considering a reference cell, with relation to others, as a living membrane bounded by two phases which in themselves are animate and between which relatively external and internal situations may be visualized. Here, though dynamic, the two phases are assumed to approach an interrelated steady state at any instant of time.

The energy levels (22) as well as the mechanics are designed to apply for water as well as for solute flux (11). The osmotic equation $(3,10)$, comprising several factors, is not involved in its parts, but only from the standpoint of the resultant energy difference between phases - the net diffusion pressure deficit of water (cf. 3). Contact exchange and surface migration of solutes (15) may be envisioned in the scheme. The constituent component $\mathrm{X}$ may be thought of as either supplied initially in the external medium or arising within the cytoplasm through metabolism. In the latter case, water and especially organic acids (4) from metabolic processes may be involved. Organic acids are particularly concerned with the differential accumulation of ions of opposite charge, by plants (24).

This diagram will be of use to the investigator who, it is assumed, has some previous knowledge of suggested steps in the over-all process, as well as familiarity with previously published literature on the subject. The instructor, similarly qualified, will find the same of service in presenting the general problem to students in the biological sciences.

\section{DISCUSSION}

With living organisms under appropriate conditions, substances will tend to move independently, each constituent solute component or water tending to move with the direction in which its energy intensity (2) decreases. Under all conditions, the tendency for movement at any instant will be completely expressed in terms of the net specific free energy causing a constituent component to tend to move through or across cytoplasm interposed between two inanimate aqueous solution phases, viz., the net influx specific free energy (NIF) where (2) 


$$
\mathrm{NIF}=\Sigma \mathrm{IF}-\Sigma \mathrm{EF} .
$$

The rate of net movement of a constituent substance is proportional to the net influx specific free emergy gradient (NIFG), where the coefficient of proportionality $(k)$ is determined by the physico-chemical properties of the cytoplasm. In other words, the rate of net influx is equal to the product of a flux coefficient or the "permeability" of the cytoplasm and the gradient of the net energy intensity, i.e.,

$$
\mathrm{RNI}=\mathrm{k} \times \mathrm{NIFG} \text {. }
$$

Here, this gradient is a measure of the space rate of the net influx specific free energy with dimensions of $\mathrm{mL}-2 \mathrm{t}-2$. The "permeability", a property of the cytoplasm, is defined to be equal to the mass of a constituent component which moves, in unit time, through a unit area of "membrane" under a unit gradient of net energy intensity.

A dimensional analysis of the "permeability" of the cytoplasm and the rate of net influx of a constituent solute species, or water, in solution may be outlined as follows : the flux coefficient or "permeability" is defined by the dimensional relation

$$
\mathrm{K}=\frac{\mathrm{m}}{\mathrm{t}} \dot{\mathrm{n}} \frac{1}{\mathrm{~L}^{2}} \times \frac{1}{\frac{\mathrm{m}}{\mathrm{Lt}^{2}} \frac{\mathrm{l}}{\mathrm{L}}}=\mathrm{t}
$$

the rate of net influx is defined by the dimensional relation

$$
\mathrm{RNI}=\mathrm{t} \times \frac{\mathrm{m}}{\mathrm{L} \mathrm{t}^{2}} \times \frac{1}{\mathrm{~L}}=\frac{\mathrm{m}}{\mathrm{L}^{2} \mathrm{t}}=\mathrm{mL}-2 \mathrm{r}-1
$$

The permeability may depend in part on partition coefficients (1) of the substance $\mathrm{X}$ in effective cytoplasmic solvents, or other physiological characteristics. Since the thickness of the cytoplasmic membrane in any particular case is not known 
with any accuracy, yet assumed to be constant during time $t$, the flux coefficient has been expressed more practically by omission of this factor (membrana thickness) from expressions $c$ and $d$. The dimensions of "permeability" are then tL-1 (Cf. (1) ); those of rate of net influx are the same as before, viz, $\mathrm{mL}-2 \mathrm{t}-1$.

The net influx specific free energy, represented dimensionally by $\frac{m}{L t^{2}}$ in equations $c$ and $d$, may be computed at the steady state, from the difference between $\Sigma$ IF and $\Sigma \mathrm{EF}$, i. e., equal to the difference in diagramatic levels of XFe and XFi as shown in the diagram $(2,3,4)$.

The physiological "thickness" of the ectoplasm and the endoplasm may vary inversely, determined bv environmental factors (aeration, etc.), through modified rates of physico-chemical processes, whitin limits determined by the genetic characteristics of the organism. The mesoplasm here merely express a transitional condition of cytoplasm, of indefinite, and possibly inconsequential thickness. The permeability of the cytoplasm is likewise determined by rates of processes within various parts thereof, limited by hereditary potentialities of the individual predetermined by its ancestry.

\section{SUMMARY}

A generalized comprehensive scheme concerning the movement of materials into living cells and tissues is presented. It is designed for use by investigators and teachers who, is assumed, have a previous knowledge of the subject as well as familiarity with previously published literature on the subject. 


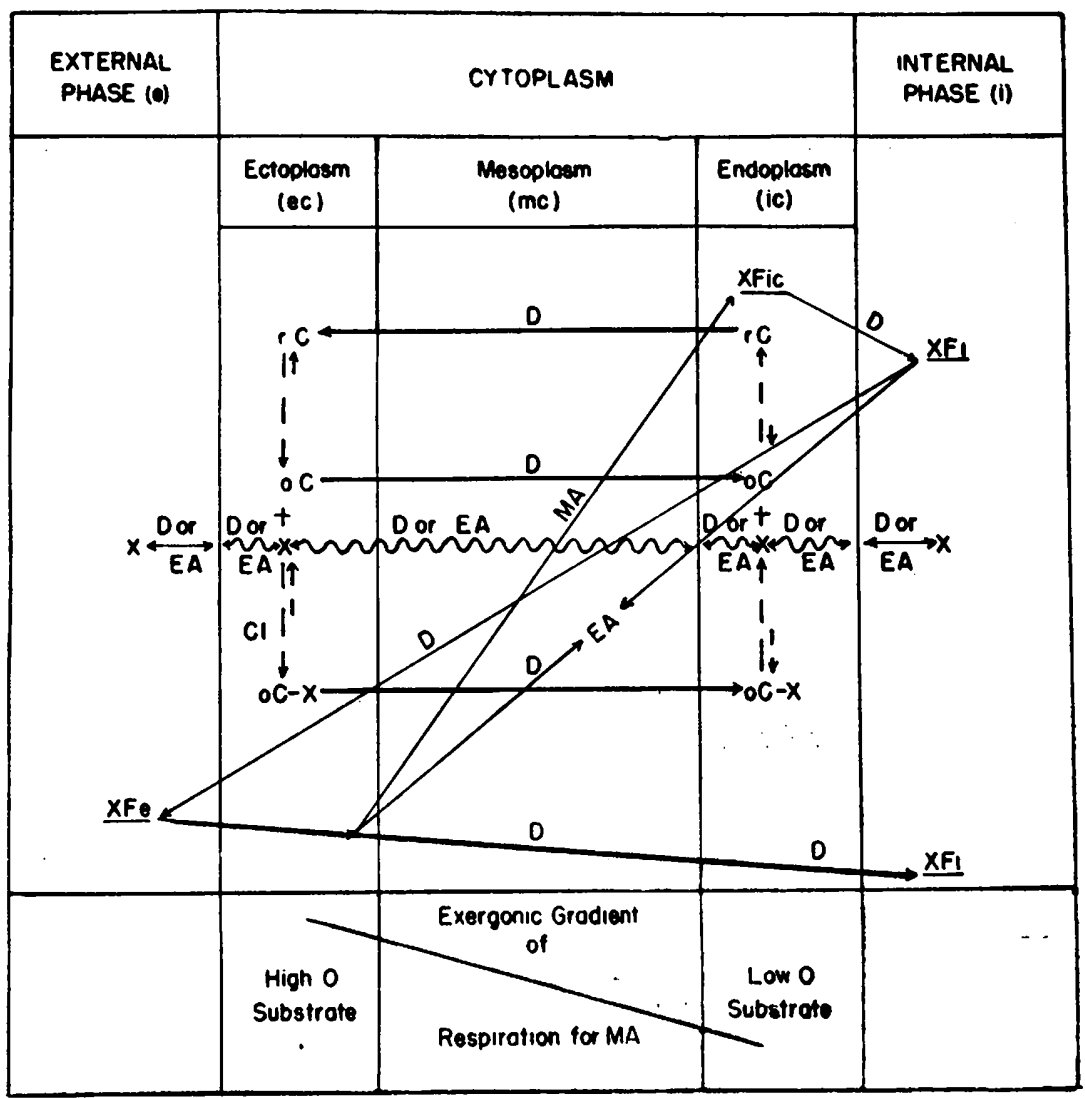

Fig. 2 - Schematic, generalized diagram of the nature of the processes of movement of materials across protoplasm interposed in a two phased system. Notes for figure

2; see next page

\section{Footnotes to figure 2}

$\mathrm{X}=\mathrm{a}$ constituent component material, arising from exter mal sources or through metabolism, capable of migration under favorable conditions.

$\mathrm{e}, \mathrm{i}, \mathrm{ec}, \mathrm{ic}, \mathrm{mc}=$ subscripts indicating location. 
$\mathrm{oC}=$ oxidized cytoplasmic constituents specifically concerned in unidirectional (here invardly directed), diffetial translocation of a particular material $\mathrm{X}$.

rC $=$ reduced cytoplasmic constituents specifically concerned

$\mathrm{XF}=$ specific free energy (2) of a constituent component in in external or internal phases or in cytoplasm.

$\mathrm{D}=$ diffusion (4).

$\mathrm{EA}=$ exchange adsorption (4).

$\mathrm{MA}=$ metabolic accumulation (4) .

CI = differentially characteristic cytoplasmic interaction (4) between oC and X, determined by the genetic constitution of the biological species.

$\longrightarrow=$ migration, where permeability to the material involved is relatively high; and mump, where relatively low.

$\leftrightarrow \cdots \cdots \cdots=$ chemical reactions.

$\longrightarrow=$ energy changes of $\mathrm{X}$; diffusion is characteristically with the direction in which the concentration or activity of the constituent decreases, exchange adsorption may be with or against the direction of concentration or activity decrease.

\section{LITERATURA CITADA}

1. Brooks, S. C. and Brooks, M. M. The Permeability of Living Cells. Protoplasma Monographien 19 : 1-395. 1941.

2. Broyer, T. C. The movent of substances through a twophased solution system. Science 105 : 67-68. 1947.

3. Broyer, T. C. The movement of materials into plants. I. Osmosis and the movement of water into plants. Bot. Rev. 13: 1-58. 1947. 
4. Broyer, T. C. The movement of materials into plants. II The Nature of solute movement into plants. Bot. Rev. 13: 125-167. 1947.

5. Broyer, T. C. The nature of the process of inorganic solute accumulation in roots. In Symposium on Mineral Nutrition of Plants. Univ. of Wisc. Press. Madison, Wisc. pp. 187-249. 1951.

6. Bull, H. B. Physical Biochemistry. John Wiley and Sons. N. Y. 1943.

7. Bull, H. B. and Gray, J. S. Secretion of hydrochloric acid by the stomach. Gastroenterology 4: 175-182. 1945.

8. Burstrom, $\mathrm{H}$. Transport of water and mineral nutrients. In Symposium on Mineral Nutrition of Plants. Univ. of Wisc. Press., Madison, Wisc. pp. 251-260, 191.

9. Crafts, A. S. and Broyer, T. C. Migration of salts and water into xylem of the roots of higher plants. Amer. Jour. Botany 25: 529-535. 1938.

10. Crafts, A. S., Currier, H. B. and Stocking, C. R. Water in the Physiology of Plants. Cronica Botanica Co. Waltham, Mass. 1949.

11. Franck, J. and Meyer, J. E. An osmotic diffusion pump. Archives Blochem. 14: 297-313. 1947.

12. Hoagland, D. R. and Broyer, T. C. Accumulation of salt and permeability in plant cells. Jour. Gen. Physiol. 25: 865880. 1942.

13. Hollander, F. The composition and mechanism of formation of gastric acid secretion. Science 110: 57-63. 1949.

14. Jacobson, L. and Overstreet, R. Study of the mechanism of ion absorption by plant roots using radioactive elements. Amer. Jour. Botany 34: 415-420. 1947.

15. Jenny, H. Contact phenomena between plant roots and soil colloids. In Symposium on Mineral Nutrition of Plants. Univ. of Wisc. Press., Madison Wisc., pp. 107-132. 1951. 
16. Lundegardh, $\mathbf{H}$. Investigations as to the absorption and accumulation of inorganic ions. Annals Agric. College Sweden 8: 234-404. 1940.

17. Lundegardh, $H$. Absorption, transport and exudation of inorganic ions by the roots. Arkiv For Botanik 32A: 1-139. 1945.

18. Overstreet, R. and Jacobson, L. Mechanisms of ion absorption by roots. Ann. Rev. Pl. Physiol. 3: 189-206. 1952.

19. Robertson, R. N. and Wilkins, M. J. Studies in the metabolism of plant cells. Australian Jour. Sci. Res. Series B. 1: 17-37. 1948.

20. Rosenberg, T. On accumulation and active transport in biological systems. I. Thermodynamic considerations. Acta Chemica Scandinavica 2: 14-33. 1948.

21. Patterson, W. B. and Stetten, De Witt Jr. A study of gastric $\mathrm{HCl}$ formation. Science 109: 256-258. 1949.

22. Russell, M. B. Soil aeration and plant growth. Manuscript 1950.

23. Spiegelman, S. and Reiner, J. M. A kinetic analysis of potassium accumulation and sodium exclusion. Growth 6 : 367-389. 1942.

24. Ulrich, A. Metabolism of non-volatile organic acids in excised barley roots as related to cation-anion balance during salt accumulation. Amer. J. Bot. 28: 526-537. 1941.

25. Ussing, H. H. Transport of ions across cellular membranes. Physiol. Rev. 29: 127-155. 1949. 